\title{
Effects of High-Grain Diet on the Quality of Meat and Carcass of Lambs and Economic Indices of Various Diets
}

\author{
Hélia Maria de S. Leite ${ }^{1}$, Nayane V. Batista ${ }^{2}$, Allison F. de Lima ${ }^{3}$, Salenilda S. Firmino ${ }^{4}$, Ana Paula P. de Assis ${ }^{4}$, \\ Maria Vivianne F. G. de Miranda ${ }^{4}$, Vitor Lucas de L. Melo ${ }^{4}$, Renata N. de Lima ${ }^{5} \&$ Patrícia de O. Lima ${ }^{4}$ \\ ${ }^{1}$ Department of Agronomic Engineering, Federal University of Sergipe, São Cristóvão, Brazil \\ ${ }^{2}$ Department of Animal Science, Federal University of São Francisco Valley, Petrolina, Brazil \\ ${ }^{3}$ Santa Cruz State University, Ilhéus, Brazil \\ ${ }^{4}$ Department of Animal Sciences, Federal Rural University of the Semi-Arid, Mossoró, Brazil \\ ${ }^{5}$ Federal Institute of Education, Science and Technology of Rio Grande do Norte, Ipanguaçu, Brazil \\ Correspondence: Vitor Lucas de L. Melo, Department of Animal Sciences, Federal Rural University of the Semi- \\ Arid, Mossoró, Brazil. Tel: 55-84-9-8739-1917. E-mail: vitor_llm@hotmail.com
}

Received: December 21, 2020

doi:10.5539/jsd.v14n1p60

\author{
Accepted: January 7, 2021 \\ Online Published: January 8, 2021
}

URL: https://doi.org/10.5539/jsd.v14n1p60

\begin{abstract}
The Brazilian sheep farming sector suffers from low productivity, related to the extensive animal production system and low availability of native fodder during most of the year. An alternative to the systems would be the use of a diet without roughage, allowing greater weight gain and better quality carcasses. The aim of this study was to investigate the effects of diets containing different proportions of grains on the quality of carcass and meat of lambs as well as the economic indices of various diets. Three diets containing different proportions of concentrate and roughage (100:0, 80:20, and 60:40) were supplied. The concentrate comprised $85 \%$ whole-grain corn and $15 \%$ commercial pelletized supplement. Twenty-four male lambs (no racial pattern; average body weight, $20.9 \pm 1.0 \mathrm{~kg}$; age, 6 months) were randomly allotted to three collective bays for 52 days. Subsequently, the animals were slaughtered, and further analyses were performed. The diet with $100 \%$ concentrate achieved overall higher carcass yield, lower weight loss on cooking, and greater lipid oxidation. However, no diet affected weight gain, slaughter weight, carcass length and thorax depth, $\mathrm{pH}$, temperature, color, water-holding capacity, and meat shear force $(\mathrm{P}>0.05)$. The best economic indices were obtained with the diet containing $100 \%$ concentrate. Therefore, based on the results obtained, the use of $100 \%$ concentrated diet for lambs is the most suitable practice to improve the sheep production from a productive and economic point of view.
\end{abstract}

Keywords: diet, high-grain diet, production cost, sheep farming

\section{Introduction}

The northeastern region of Brazil contains $57.5 \%$ of effective sheep herds in the national territory, despite 5 consecutive years of drought. In the last 3 years, the volume of sheep herds has increased by $4.5 \%$ per year, thus making this region a hotspot of sheep farming. Although the sheep farming sector suffers from low productivity, typically related to the extensive animal production system and low availability of native fodder during most of the year, even today, this practice remains active despite the many adversities. Regardless of these challenges, the breeders' ability to adapt to a new productive reality is reflected in the increase in herd volume in recent years (Embrapa, 2016).

Recent devaluation of the Brazilian currency may endow national products (milk, meat, skin, and wool) with better competitiveness abroad, providing better remuneration to producers who trade in higher currency. This is a positive aspects when combined with factors such as improved genetics, health, and nutrition as well as reduced production cost. Nonetheless, there remain challenges to be overcome, including maintenance of the quality of meat and standardization of the exportable products (Embrapa, 2016).

Termination of lambs in an extensive production system results in the slaughter of older animals. The possibility of slaughtering animals earlier and obtaining better-quality carcass reflects a higher price paid by the consumer and guarantees the producer a faster return on the invested capital. However, this productive strategy requires 
additional investments, such as animal facilities and, particularly, feed (Almeida Júnior, 2004).

In Brazil, the use of diets without roughage for cattle began in 2005 to meet the need for achieving greater weight gain in shorter time and better quality carcasses. However, in the United States, such diets have been used since the 1970s. In sheep farming, this practice is still considered recent (around 3-year old) and is not yet widespread in the northeastern region of Brazil (Grandini, 2015). Considering the high prevalence of droughts in this region, the advantages of adopting this practice include the low cost of producing roughage, constant feed supply, and reduced mortality due to diseases. Since sheep farming closely depends on grazing, animals with meat of superior physical and chemical quality need to be produced in a short period.

From these perspectives, termination of lambs must be intensified and mechanized to increase commercialization, anticipating the age at slaughter and promoting the production of good-quality carcass that meets consumer demands. According to Costa et al. (2002), genotype, slaughter weight, sex, production system, and diets, in particular, should be considered during production planning, prioritizing the nutritional and sensory qualities of meat, as a way to meet new market trends while maintaining an adequate cost-benefit ratio.

Thus, the proportion of roughage and concentrate in feed is crucial, as roughage type affects sheep meat quality. High roughage proportion in feed produces darker meat due to higher myoglobin levels in muscles (Priolo et al., 2002) or yellow meat due to greater accumulation of carotenoids in fat (Prache et al., 2003). Lambs fed diets containing more concentrate produce softer meat (Ciria and Asenjo, 2000) due to higher intramuscular fat content (Leão et al., 2011).

To this end, the present study evaluated the carcass characteristics, meat quality, and production costs of lambs finished in confinement and fed high-grain diets.

\section{Method}

\subsection{Experimental Characterization}

The experiment was conducted at a property in São Pedro in the municipality of Pedro Avelino $\left(5^{\circ} 31^{\prime} 21^{\prime \prime} \mathrm{S}\right.$, $36^{\circ} 23^{\prime} 14^{\prime \prime} \mathrm{W}$ ), Rio Grande do North, Brazil. The use of animals and all experimental procedures were approved by the Ethics Committee on the Use of Animals of the Federal Rural University of the Semi-Árido (UFERSA) (protocol \#23091.002579 / 2016-21).

The treatments comprised the supply of three diets containing different levels of concentrate $(100 \%, 80 \%$, and $60 \%$ ). The concentrate comprised $85 \%$ whole-grain corn and $15 \%$ commercial pelletized protein-mineral-vitamin supplement, used for fattening cattle. The roughage was Tifton hay (Cynodon sp.) (Table 1). 
Table 1. Bromatological composition of ingredients and experimental diets

\begin{tabular}{|c|c|c|c|c|c|}
\hline \multirow[b]{2}{*}{ Composition $\left(\mathrm{g} \cdot \mathrm{kg}^{-1} \mathrm{DM}\right)$} & \multirow[b]{2}{*}{$\begin{array}{l}\text { Concentrate ( } 85 \% \text { corn } \\
+15 \% \text { supplement) }\end{array}$} & \multirow[b]{2}{*}{$\begin{array}{c}\text { Tifton } \\
\text { hay }\end{array}$} & \multicolumn{3}{|c|}{ Diets } \\
\hline & & & 100 & $80: 20$ & $60: 40$ \\
\hline $\mathrm{DM}(\%)$ & 89.14 & 92.4 & 89.14 & 89.79 & 90.1 \\
\hline MM & 8.04 & 5.8 & 8.04 & 7.59 & 7.46 \\
\hline $\mathrm{CP}$ & 16.35 & 9.3 & 16.35 & 14.98 & $12.21-$ \\
\hline $\mathrm{EE}$ & 2.97 & 1.25 & 2.97 & 2.78 & 2,58 \\
\hline NDF & 36.91 & 77.2 & 36.91 & 44.96 & 54.5 \\
\hline $\mathrm{ADF}$ & 7.06 & 46.6 & 7.06 & 14.98 & 23.15 \\
\hline Hemicellulose & 29.85 & 30.6 & 29.85 & 29.98 & 31.35 \\
\hline $\mathrm{TC}$ & 72.51 & 83.0 & 72.51 & 73,6 & 75.6 \\
\hline NFC & 35.60 & 21.7 & 35.60 & 28.48 & 22.78 \\
\hline Lignin & 2.16 & 8.3 & 2.16 & 3.32 & 4.70 \\
\hline Cellulose & 4.91 & 38.3 & 4.91 & 11.66 & 18.45 \\
\hline $\mathrm{TDN}$ & 71.48 & 60.95 & 71.48 & 71.19 & 72.1 \\
\hline Digestible energy $\left(\mathrm{Mcal} \cdot \mathrm{kg}^{-1}\right)$ & 3.15 & 2.68 & 3.15 & 3.13 & 3.17 \\
\hline
\end{tabular}

DM, dry matter; MM, mineral matter; CP, crude protein; EE, ether extract; NDF, neutral detergent fiber; ADF, acid detergent fiber; TC, total carbohydrates; NFC, non-fibrous carbohydrates; TDN, total digestible nutrients

Twenty-four uncastrated male lambs were used, with no defined racial pattern (age, 6 months; initial body weight, $20.9 \pm 1.0 \mathrm{~kg}$ ). The animals were allotted to three collective bays (one bay per treatment) in a completely randomized design. Each bay measured $29 \mathrm{~m} 2$. The bays were cemented and half-covered and were equipped with a solarium, a linear feeder collective $(0.25 \mathrm{~m} \cdot$ animal-1), saltshakers, and drinking fountains.

The experiment lasted 52 days: 10 days for acclimatizing the animals to the facilities and food consumption and 42 days for data collection. The diet was divided into three daily meals, at 6,12 , and 18 hours. The offered volume of diet was adjusted daily to allow a $10 \%$ daily leftover, ensuring ad libitum access. To record daily consumption, the leftover of the previous day was collected and weighed before the first meal on the next day.

According to information from the manufacturer, ingredients of the commercial supplement used were soybean meal; ground corn; wheat bran; ground gluten bran; rice bran; ground soy husk; molasses; limestone; sodium chloride; iron sulfate; manganese monoxide; zinc sulfate; calcium iodate; cobalt sulfate; sodium; selenite; vitamins A, D3, and E; ammonium chloride; ammonium propionate; and sodium monensin.

At the end of the experimental period, the animals were slaughtered following humane practices conforming to the requirements of the Ministry of Agriculture (Riispoa, 1997).

\subsection{Sampling Procedures and Experimental Manipulations}

For each animal, body weight at slaughter (SBW) was recorded after 16 hours of solid fasting. After removal of the viscera, the non-integrating components of the carcass, such as the blood, head, feet, skin, tongue, heart, respiratory tract, esophagus, spleen, liver, kidneys, pancreas, full and empty gastrointestinal tract, full and empty bladder, and reproductive tract (penis and testicles), were weighed. The carcasses were weighed after evisceration and removal of the head and limb extremities, obtaining hot carcass weight (HCW).

Moreover, carcass length (LC) and thorax depth (PT) (defined as the maximum distance between the external bone and dorsum of the carcass) were measured. $\mathrm{pH}$ and temperature of hot carcass (temperature 0 and $\mathrm{pH} 0$, respectively, measured 30 minutes after slaughter) were measured using a digital $\mathrm{pH}$ meter (previously calibrated) and thermometer, respectively, based on two readings in different regions.

After weighing and measuring, the half-carcasses were labeled and cooled to $4 \pm 0.5^{\circ} \mathrm{C}$ for 24 hours to establish rigor mortis. After cooling, temperature and $\mathrm{pH}$ of the cold carcass were obtained (temperature 24 and $\mathrm{pH} 24$, respectively, measured 24 hours post mortem), with two measurements at different locations on legs. 
Cold carcass weight $(\mathrm{CCW})$ was obtained after the cooling period, and carcass yield $(\mathrm{CY})$ was calculated using the following equation: $\mathrm{CY}(\%)=(\mathrm{CCW} / \mathrm{SBW}) \times 100$.

To determine the physicochemical characteristics of meat, the lumborum muscle was removed from each carcass, packed in a labeled bag, and transported in a thermal box with ice to UFERSA for analysis.

Physical analysis of meat was performed in the Laboratory of Instrumental and Sensory Analysis of UFERSA. The following parameters were evaluated: $\mathrm{pH}$, temperature, color, shear force (SF), water-holding capacity (WHC), and weight loss on cooking (WLC).

$\mathrm{pH}$ of the samples was determined according to the methodology established by AOAC (2005) using a digital $\mathrm{pH}$ meter (Hanna brand) coupled to a penetration electrode.

Color was evaluated using the Konica Minolta colorimeter CM-700d / 600d (CIE System L*a*b*); this system considers the coordinates L* (luminosity, black/white), a* (red content, green/red), and b* (yellow content, blue/yellow).

WHC was measured using the methodology adapted from Hamm (1961). Briefly, $2 \mathrm{~g}$ of meat cubes were weighed, first placed between two filter papers, then placed between two acrylic plates, and finally a weight of $5 \mathrm{~kg}$ was applied for 5 minutes. The weight and filter papers were removed, and the samples were weighed again.

To measure WLC, three portions of the muscle $(3.0 \times 3.0 \times 2 \mathrm{~cm} 3)$ were removed, weighed, wrapped in aluminum foil, and grilled until reaching an internal temperature of $70^{\circ} \mathrm{C}$, as monitored by a mercury thermometer. Subsequently, the samples were cooled to room temperature and weighed again, and WLC was obtained based on weight difference.

To determine SF, the same samples used to measure WLC were used. SF was measured using a texturometer (TEXTURE ANALYZER TA-XT-125) coupled to the Warner-Bratzler device (HDP / WBV) with the following configurations: pretest speed, $2.0 \mathrm{~m} \mathrm{~s}-1$; test speed, $3.0 \mathrm{~m} \mathrm{~s}-1$; distance traveled by the slide after reaching the top of the sample, $20 \mathrm{~mm}$; posttest speed, $10 \mathrm{~m} \mathrm{~s}-1$; and configurations for a 1.5-cm-high sample.

Chemical composition of meat was determined in the Animal Nutrition Analysis Laboratory of UFERSA. Moisture, mineral matter, and protein content were quantified according to the methodology described by AOAC (2000), and lipid content was quantified using the method proposed by Folch et al. (1957).

The test of substances reactive to thiobarbituric acid (TBARS) was also performed, in which the positive samples developed a pink color during heating, and the absorbance of the solution was determined at $532 \mathrm{~nm}$ against blank.

To evaluate production costs, only additional feeding expenses were considered. Economic indices were calculated as described by Lima et al. (2012), considering a 100\% concentrated diet as a reference. The following indices were evaluated:

- Total revenue (reais per animal): price per kilogram of carcass multiplied by carcass yield in kilograms per animal

- Additional revenue (reais per animal): difference between the total revenue obtained per treatment and the total revenue obtained for the reference diet

- Total feed cost (reais per animal): total feed cost per treatment

- Additional cost of feed (reais per animal): difference between the total cost of feed obtained per treatment and the total cost

- Additional profit (reais per animal): difference between the value of addition to the additional revenue and the value of the addition to the expenditure on food

Costs of ingredients and carcass used in the analysis refer to values in the local market during the experimental period: $1.55 \mathrm{R} \$ \cdot \mathrm{kg}-1$ for supplement; $0.60 \mathrm{R} \$ \mathrm{~kg}-1$ for corn; $1.17 \mathrm{R} \$ \cdot \mathrm{kg}-1$ for hay, and $13.00 \mathrm{R} \$ \cdot \mathrm{kg}-1$ for sheep meat in the carcass.

The results were subjected to analysis of variance, and the means were compared by the Tukey test. A significance level of 5\% was adopted, and all analyses were performed using the statistical package SAS (2004).

\section{Results}

Diet did not affect weight gain, SBW, HCW, CCW, CL, and PT across treatments $(\mathrm{P}>0.05)$ (Table 2).

CY was influenced by diet $(\mathrm{P}<0.05)$. CY of lambs that received a $100 \%$ concentrated diet was the highest. There was no difference in $\mathrm{CY}$ between the remaining two diets $(\mathrm{P}<0.05)$. 
Concentrate level affected gastrointestinal content $(\mathrm{P}<0.05)$. After slaughter, the gastrointestinal content of animals that received a $60 \%$ concentrated diet was higher than that of animals that received diets with less roughage.

Table 2. Carcass characteristics of lambs fed with high-grain diets

\begin{tabular}{cccccc}
\hline \multirow{2}{*}{ Variables } & \multicolumn{3}{c}{ Concentrate $(\%)$} & \multirow{2}{*}{ CV } & P-value \\
\cline { 2 - 4 } & 100 & 80 & 60 & & \\
\hline Initial weight $(\mathrm{kg})$ & 21.0 & 20.9 & 20.9 & 2.7 & $<0.001$ \\
Consumption $\left(\mathrm{g} \cdot \mathrm{kg}^{-1} \mathrm{DM}\right)$ & 0.675 & 0.592 & 0.523 & 23.54 & 0.20 \\
Weight gain $(\mathrm{kg})$ & 12.7 & 10.7 & 10.9 & 2.3 & 0.29 \\
Final weight $(\mathrm{kg})$ & 33.7 & 31.6 & 31.8 & 3.6 & 0.66 \\
Hot carcass $(\mathrm{kg})$ & 17.1 & 15.0 & 14.7 & 2.1 & 0.11 \\
Cold carcass $(\mathrm{kg})$ & 16.1 & 13.8 & 13.8 & 2.0 & 0.06 \\
Gastrointestinal content $(\mathrm{kg})$ & $6.3^{\mathrm{b}}$ & $6.3^{\mathrm{b}}$ & $7.6^{\mathrm{a}}$ & 1.0 & 0.03 \\
Carcass yield $(\%)$ & $47.9^{\mathrm{a}}$ & $43.5^{\mathrm{b}}$ & $43.4^{\mathrm{b}}$ & 2.5 & $<0.01$ \\
Carcasses length $(\mathrm{cm})$ & 0.79 & 0.77 & 0.77 & 0.5 & 0.57 \\
Chest thorax $(\mathrm{cm})$ & 0.31 & 0.32 & 0.30 & 0.5 & 0.18 \\
\hline
\end{tabular}

$\mathrm{CV}$, coefficient of variation; DM, dry matter

Different superscript letters in the same row indicate significant differences $(\mathrm{P}<0.05)$.

Diet did not affect physical parameters, including $\mathrm{pH}$, temperature, color, WHC, and SF (Table 3). WLC was lower for the meat of lambs fed a $100 \%$ concentrated diet $(\mathrm{P}<0.05)$; there were no differences in WLC for the meat of lambs fed $60 \%$ and $80 \%$ concentrated diets.

Table 3. Physical characteristics of the meat of lambs fed with high-grain diets

\begin{tabular}{cccccc}
\hline \multirow{2}{*}{ Variables } & \multicolumn{3}{c}{ Concentrate $(\%)$} & \multirow{2}{*}{ CV } & P-value \\
\cline { 2 - 4 } & 100 & 80 & 60 & & 0.03 \\
\hline $\mathrm{pH}^{0}$ & 6.8 & 6,7 & 6,8 & 0.21 \\
$\mathrm{pH}^{24}$ & 5.6 & 5.8 & 5.7 & 0.03 & 0.19 \\
Temperature $\left({ }^{\circ} \mathrm{C}\right)$ & 31.1 & 31.6 & 31.0 & 0.21 & 0.69 \\
Temperature ${ }^{24}\left({ }^{\circ} \mathrm{C}\right)$ & 2.8 & 3.2 & 2.9 & 0.20 & 0.50 \\
$\mathrm{~L}^{*}$ & 41.6 & 40.7 & 40.8 & 3.5 & 0.77 \\
$\mathrm{a}^{*}$ & 9.3 & 10.4 & 10.0 & 1.6 & 0.40 \\
$\mathrm{~b}^{*}$ & 11.6 & 11.3 & 11.6 & 1.9 & 0.71 \\
$\mathrm{WHC}(\%)$ & 75.7 & 71.1 & 72.5 & 9.2 & 0.09 \\
$\mathrm{WLC}(\%)$ & $31.4^{\mathrm{a}}$ & $35.5^{\mathrm{b}}$ & $35.4^{\mathrm{b}}$ & 5.7 & 0.04 \\
$\mathrm{SF}\left(\mathrm{kg} \cdot \mathrm{cm}^{-2}\right)$ & 4.0 & 3.8 & 3.6 & 0.52 & 0.47 \\
\hline
\end{tabular}

WHC, water holding capacity; WLC, weight loss on cooking; SF, shear force; $\mathrm{CV}$, coefficient of variation

Different superscript letters in the same row indicate significant differences $(\mathrm{P}<0.05)$.

Diet did not affect the chemical composition of meat $(\mathrm{P}>0.05)$ (Table 4). However, diet significantly affected TBARS $(\mathrm{P}<0.05)$, and lipid oxidation rate was higher in the meat of lambs fed a $100 \%$ concentrated diet than that in the meat of lambs fed $60 \%$ and $80 \%$ concentrated diets. 
Table 4. Chemical composition of the meat of lambs fed with high-grain diets

\begin{tabular}{ccccccc}
\hline \multirow{2}{*}{ Variables (\%) } & \multicolumn{3}{c}{ Concentrate (\%) } & \multirow{2}{*}{ CV } & P-value \\
\cline { 2 - 4 } & 100 & 80 & 60 & & 0.83 & 0.43 \\
Moisture & 70.0 & 70.3 & 70.7 & 0.055 & 0.01 \\
Mineral matter & 1.4 & 1.3 & 1.4 & 1.00 & 0.56 \\
Protein & 17.6 & 17.7 & 17.8 & 0.40 & 0.27 \\
Lipids & 1.6 & 1.7 & 1.3 & 0.42 & 0.02 \\
TBARS (\%) & $0.86^{\mathrm{a}}$ & $0.40^{\mathrm{b}}$ & $0.36^{\mathrm{b}}$ & & \\
\hline
\end{tabular}

$\mathrm{CV}$, coefficient of variation; TBRS, thiobarbituric acid

Different superscript letters in the same row indicate significant differences $(\mathrm{P}<0.05)$.

Table 5 shows the cost revenue and economic indices of various diets offered to the lambs during the termination period. The $100 \%$ concentrated diet obtained a higher carcass weight than other diets. The indicators of food consumption and profit were also superior for the $100 \%$ concentrated diet.

Table 5. Economic indices of high-grain diets

\begin{tabular}{cccc}
\hline Economic index & \multicolumn{3}{c}{ Concentrate (\%) } \\
\cline { 2 - 4 } & 100 & 80 & 60 \\
\hline Carcass weight $\left(\mathrm{kg} \cdot \mathrm{animal}^{-1}\right)$ & 16.10 & 13.80 & 13.80 \\
Additional carcass weight $\left(\mathrm{kg} \cdot \mathrm{animal}^{-1}\right)$ & - & -2.3 & -2.3 \\
Meat price $\left(\mathrm{R} \$ \cdot \mathrm{kg}^{-1}\right)$ & 13.00 & 13.00 & 13.00 \\
Total diet consumption $\left(\mathrm{kg} \cdot\right.$ animal $\left.^{-1}\right)$ & 31.794 & 27.720 & 24.400 \\
Cost per kilogram of meat $(\mathrm{R} \$)$ & 1.97 & 2.00 & 1.76 \\
Cost of diet $\left(\mathrm{R} \$ \cdot \mathrm{kg}^{-1}\right)$ & 0.938 & 0.984 & 1.031 \\
Total revenue $2\left(\mathrm{R} \$ \cdot\right.$ animal $\left.^{-1}\right)$ & 209.30 & 179.40 & 179.40 \\
Additional revenue $\left(\mathrm{R} \$ \cdot\right.$ animal $\left.^{-1}\right)$ & - & -29.90 & -29.90 \\
Total cost $(\mathrm{R} \$ \cdot$ animal & -1 \\
Cost of additional feeding $\left(\mathrm{R} \$ \cdot\right.$ animal $\left.^{-1}\right)$ & 29.82 & 27.28 & 25.16 \\
Additional profit $\left(\mathrm{R} \$ \cdot\right.$ animal $\left.^{-1}\right)$ & - & -2.54 & -7.39 \\
\hline
\end{tabular}

Values were calculated by the authors.

\section{Discussion}

In the present study, the effects of different levels of concentrate in high-grain diets on the carcass characteristics and meat quality of sheep without a racial pattern were evaluated.

Initial weights indicated the balance between the experimental units evaluated, since the lambs, regardless of treatment, showed homogeneous characteristics of genotype, sex, and age at the beginning of the experiment; thus, the noted differences represent a direct consequence of the diet supplied.

The results observed for weight gain, SBW, $\mathrm{HCW}, \mathrm{CCW}, \mathrm{CL}$, and PT across treatments showed that despite different nutritional compositions, the tested diets could meet the demands of animals without bias.

Differences in CY observed in this study can be attributed to gastrointestinal content after slaughter. CY has been reported to be strongly affected by gastrointestinal contents of animals at the time of slaughter. Increased concentrate level in the diet can decrease the maintenance energy required, thus contributing to better food assimilation by the animal. According to Owens and Goetsch (1988), forage intake has a greater impact on rumen volume than concentrate intake; consequently, greater rumen volume and tissue mass are accompanied by higher energy consumption by gastrointestinal tissues, corroborating the findings of the present study. Consistent with 
this, the gastrointestinal tract, liver, kidneys, and spleen are metabolically active tissues and consume over $50 \%$ of the energy used to maintain the body as a whole.

Pires et al. (2006) evaluated the carcass characteristics of Ile de France $\times$ Texel crossbred lambs finished in confinement and fed diets containing different fiber levels. They observed that decreased neutral detergent fiber (NDF) content of the diet improved CY of animals. Therefore, adoption of this feeding strategy is important from a productive point of view, as a smaller or larger portion of edible material from CY becomes available for commercialization and consumption after the slaughter of animals.

$\mathrm{pH}^{24}$ recorded in this study was consistent with previously reported values for sheep meat. According to Silva Sobrinho (2005), under appropriate acidification, $\mathrm{pH}$ should be between 5.5 and 5.8. Of note, the finding of normal $\mathrm{pH}$ values in this study suggests that other parameters such as WHC, color, and SF, which are directly affected by $\mathrm{pH}$, would present satisfactory results.

Furthermore, sheep meat is superior to other types of meat, as it rarely faces problems that can compromise its quality, such as the occurrence of dry, firm, and dark or pale, soft, and exudative meat, which is considered a serious problem in the meat industry. According to Sañudo et al. (1997), sheep may to be more adapted to stresses in the ante mortem period than other species.

The means of color variable $\mathrm{L}^{*}, \mathrm{a}^{*}$, and $\mathrm{b}^{*}$ noted in this study were consistent with the values reported by Sañudo et al. (2000) for lamb meat (30.03 to 49.47 for $\mathrm{L}^{*}, 8.24$ to 23.53 for $\mathrm{a}^{*}$, and 3.38 to $11.90 \mathrm{for}^{*}$ ). According to Sarantópoulos and Pizzinato (1990), the color cycle of fresh meat is dynamic, allowing for the constant interconversion of three forms of pigment (purple-red, bright red, and brown). Therefore, until the meat is heated to the cooking temperature, the color of the irreversible metmyoglobin is subject to changes.

Color is considered the first determinant at the time of purchase, even if it does not affect palatability. This factor reflects the quantity and chemical status of myoglobin - the main pigment of meat. In addition to exposure to oxygen and the chemical form of myoglobin, meat color is affected by myoglobin level, which varies depending on the function and location of the muscle as well as the age of the animal.

Meat WHC is one of the parameters affected by a drop in muscle $\mathrm{pH}$ after slaughter. WHC is lower at $\mathrm{pH}$ values of 5.2 to 5.3, that is, at the isoelectric point (IP) of most muscle proteins. At a pH higher than the IP of muscle proteins, the positive charges disappear, leaving an excess of negative charges that determine the repulsion of the filaments, leaving more space for water molecules and thereby causing the meat to lose water upon cooking (Roça, 2002). During the transformation of muscle into meat, $\mathrm{pH}$ drop leads to enzymatic degradation of the myofibrillar structure, which favors WHC.

Mean WLC (34.1\%) in the present study was lower than that reported by Costa et al. (2011b) for lambs without a defined racial standard (SPRD), Santa Inês lambs, and lambs of SPRD $\times$ Santa Inês crossbred sheep (38.2, 39.8, and $40.9 \%$, respectively). WLC recorded in the present study, albeit lower than the value recommended in literature, may be associated with age at slaughter. Younger animals tend to have a greater amount of water in muscles, as observed by Pinheiro et al. (2009), who compared the meat quality of lambs and adult sheep and found higher WLC for the former $(46.44 \%)$.

Mean SF recorded for the lumborum muscle in this study was consistent with values reported by Babiker et al. (1990) for the longissimus dorsi of lambs $\left(3.6\right.$ to $\left.4.2 \mathrm{~kg} \cdot \mathrm{cm}^{-2}\right)$. Therefore, under experimental conditions, all meat samples analyzed were very tender, which may be associated with the quality of diet and age of animals. Sañudo (1998) reported variable SF in young animals depending on to the age at slaughter, likely due to interactions between different rates of collagen deposition in the animal's muscle. Compared with that of older animals, the meat of young animals tends to lose its tenderness with increasing thermal stability of collagen due to the formation of cross-bridges (Marsh, 1977). Considering the long time required for the metabolic replenishment of collagen, the effect of connective tissue in young animals is insignificant, while that of other factors, such as the intensity of proteolysis and the degree of muscle tissue contraction, is profound, which makes the meat softer.

Diet did not affect the nutritional composition of meat, which is consistent with previous reports (70 to $76 \%$ moisture, 17.3 to $23.0 \%$ proteins, 2 to $4 \%$ lipids, and 0.98 to $1.6 \%$ minerals) (Rodrigues et al., 2010). Homogeneity of age and weight at slaughter among animals in different treatments can be attributed to this lack of differences in the nutritional quality of meat. Consistently, according to Bonagurio et al. (2004), maturity of the animal affects the centesimal composition of meat.

Among meat components, fat is the tissue of the greatest variability in an animal, both in terms of content and distribution, and upon increase in fat content of meat, the proportions of moisture, protein, and minerals decrease (Lawrie, 2005). Given the comparable fat content of the meat evaluated, there were no changes in the other 
characteristics.

The highest TBARS levels noted in the meat of lambs fed the $100 \%$ concentrated diet may be related to the presence of higher amounts of triglycerides, resulting from the esterification of a glycerol molecule with three fatty acids, which is considered the main factor responsible for rancidity development (Nelson and Cox, 2006). Animal feedlot systems result in a high proportion of oleic and linoleic unsaturated fatty acids due to decreased biohydrogenation by rumen bacteria.

Meat is usually rich in triacylglycerols and phospholipids, which are removed from natural protection at the time of slaughter and under blood circulation failure, ultimately undergoing oxidation (Osawa et al., 2005). Lipid oxidation is regulated through diverse and extremely complex metabolic mechanisms, which are related to the type of lipid structure and the environment in which it is found. In addition, the degree and nature of unsaturation, exposure to light and heat, and presence of metallic pro- or antioxidant factors determine the oxidative stability of lipids (Wheatley, 2000).

According to Djanane et al. (2002), TBARS levels greater than 1 milligram malonaldehyde per kilogram of meat are noteworthy. Meanwhile, according to Lira et al. (2000), to estimate rancidity development for a meat sample, TBARS levels of 0.6 to 2.0 milligram malonaldehyde per kilogram must be obtained in evaluations by a trained sensory panel. The value reported in the present study is lower than that recommended as adequate, indicating that the level of concentrate in a high-grain diet did not compromise the oxidative stability of lamb meat.

Based on the obtained cost and revenue indices, a $100 \%$ concentrated diet provided better results than the other diets. Carcass weight of lambs fed the $100 \%$ concentrated diet was higher (by $2.30 \mathrm{~kg}$ ) than that of lambs fed other diets. Although the food consumption of lambs fed the $100 \%$ concentrated diet was higher, it increased the total cost of feeding; however, the gain of $2.30 \mathrm{~kg}$ in carcass weight of animals fed the $100 \%$ concentrated diet resulted in an additional profit of 27.36 and $22.51 \mathrm{R} \$$ animal $^{-1}$ compared with the profit gained from lambs fed the $80 \%$ and $60 \%$ concentrated diets, respectively. Thus, despite significant increase in the total cost of feeding with highgrain diets, the productive response offset this increase, providing a better economic output.

Of note, profit may vary depending on the price of meat in the local market and the cost of inputs, since food shortages may increase these prices.

According to Bendahan (2017), aspects such as finishing speed, feed conversion, price, feed quality, and demand in the meat market must be considered in the option for confinement, such that the producer obtains economic gain. Therefore, each region must adapt suitable practices to meet market preferences after analyzing all these factors. Considering that profits can vary, carful economic evaluation is warranted taking risks to which the activity is exposed into account.

Therefore, for the termination of lambs in confinement to be economically viable, diets that provide a satisfactory productive performance of the animals while reducing the confinement period should be supplied, so that the total cost of the diet does not derail the use of this system.

In lamb finishing systems, a $100 \%$ concentrated diet is the most suitable practice from a productive and economic point of view, as it provides higher $\mathrm{CY}$, without compromising the physical and nutritional characteristics of meat.

\section{References}

Almeida Júnior, G. A., Costa, C., Monteiro, A. L. G., Garcia, C. A., Munari, D. P., \& Neres, M. A. (2004). Qualidade da carne de cordeiros criados em creep feeding com silagem de grãos úmidos de milho. Revista Brasileira de Zootecnia, 33(4), 1039-1047. https://doi.org/10.1590/s1516-35982004000400024

AOAC - Association of Official Analytical Chemists. (2000). Official Methods of Analysis of the Association of Official Analytical Chemists.

AOAC - Association of Official Analytical Chemists. (2006). Official Methods of Analysis (18th ed.). Aoac Intl.

Babiker, S. A., El Khider, I. A., \& Shafie, S. A. (1990). Chemical composition and quality attributes of goat meat and lamb. Meat Science, 28(4), 273-277. https://doi.org/10.1016/0309-1740(90)90041-4

Barros, N. N., Vasconcelos, V. R., Wander, A. E., \& Araújo, M. R. A. (2005). Eficiência bioeconômica de cordeiros F1 Dorper x Santa Inês para produção de carne. Pesquisa Agropecuária Brasileira, 40(8), 825-831. https://doi.org/10.1590/s0100-204x2005000800014

Bendahan, A. B. (2017). Confinamento de cordeiros: uma alternativa na ovinocultura. Agroline. Retrieved December, 2020, from http://www.agroline.com.br/ artigos/artigo.php?id=304

Bonagurio, S., Pérez, J. R. O., Garcia, I. F. F., Bressan, M. C., \& Lemos, A. L. S. C. (2003). Qualidade da carne 
de cordeiros Santa Inês puros e mestiços com Texel abatidos com diferentes pesos. Revista Brasileira de Zootecnia, 32(6 suppl 2), 1981-1991. https://doi.org/10.1590/s1516-35982003000800023

Ciria, J., \& Asenjo, B. (2000). Factores a considerar en el presacrificio y postsacrificio. In C. Sañudo, \& V. Cañeque (Eds.), Metodología para el estudio de la calidad de la canal y de la carne en rumiantes (pp. 20-45). Instituto Nacional Investigación y Tecnología Agraría y Alimentaria.

Costa, E. C., Restle, J., Brondani, I. L., Perottoni, J., Faturi, C., \& Menezes, L. F. G. (2002). Composição Física da Carcaça, Qualidade da Carne e Conteúdo de Colesterol no Músculo Longissimus dorsi de Novilhos Red Angus Superprecoces, Terminados em Confinamento e Abatidos com Diferentes Pesos. Revista Brasileira de Zootecnia, 31(1 suppl), 417-428. https://doi.org/10.1590/s1516-35982002000200017

Djenane, D., Sánchez-Escalante, A., Beltrán, J. A., \& Roncalés, P. (2002). Ability of $\alpha$-tocopherol, taurine and rosemary, in combination with vitamin $\mathrm{C}$, to increase the oxidative stability of beef steaks packaged in modified atmosphere. Food Chemistry, 76(4), 407-415. https://doi.org/10.1016/s0308-8146(01)00286-2

EMBRAPA - Empresa Brasileira de Pesquisa Agropecuária. (2016). Embrapa Caprinos e Ovinos - Portal Embrapa. Retrieved December, 2020, from https://www.embrapa.br/caprinos-e-ovinos

Hamm, R. (1961). Biochemistry of Meat Hydration. Advances in Food Research, 355-463. https://doi.org/10.1016/s0065-2628(08)60141-x

Lawrie, R. A. (2005). Ciência da carne. Artmed.

Leão, A. G., Sobrinho, A. G. S., Moreno, G. M. B., Souza, H. B. A., Perez, H. L., \& Loureiro, C. M. B. (2011). Características nutricionais da carne de cordeiros terminados com dietas contendo cana-de-açúcar ou silagem de milho e dois níveis de concentrado. Revista Brasileira de Zootecnia, 40(5), 1072-1079. https://doi.org/10.1590/s1516-35982011000500019

Lima, R. N., Lima, P. O., Aroeira, L. J. M., Miranda, M. V. F. G., Lopes, K. T. L., Diógenes, G. V., ... Rossato, C. H. (2012). Desempenho de bezerros aleitados com soro de queijo em associação ao colostro. Pesquisa Agropecuária Brasileira, 47(8), 1174-1180. https://doi.org/10.1590/s0100-204×2012000800019

Lira, G. M., Shimokomaki, M., Mancini-Filho, J., \& Torres, E. A. F. S. (2000). Avaliaçäo da oxidaçäo lipídica em carne-de-sol. Higiene Alimentar, 14, 66-69. Retrieved from https://pesquisa.bvsalud.org/portal/resource/pt/lil-256707

MARSH, B. B. (1977). The Basis of Quality in Muscle Foods THE BASIS OF TENDERNESS IN MUSCLE FOODS. Journal of Food Science, 42(2), 295-297. https://doi.org/10.1111/j.1365-2621.1977.tb01485.x

Osawa, C. C., Felício, P. E., \& Gonçalves, L. A. G. (2005). Teste de TBA aplicado a carnes e derivados: métodos tradicionais, modificados e alternativos. Química Nova, 28(4), 655-663. https://doi.org/10.1590/s010040422005000400019

Perobelli, Z. V., Müller, L., \& Restle, J. (1995). Estudo das carcaças de vacas de descarte das raças Charolês e Nelore. Pesquisa Agropecuária Brasileira, 20(3), 409-412. Retrieved from https://seer.sct.embrapa.br/index.php/pab/article/view/4322/1608

Pinheiro, R. S. B., Silva Sobrinho, A. G., Souza, H. B. A., \& Yamamoto, S. M. (2009). Qualidade de carnes provenientes de cortes da carcaça de cordeiros e de ovinos adultos. Revista Brasileira de Zootecnia, 38(9), 1790-1796. https://doi.org/10.1590/s1516-35982009000900022

Pires, A. J. V., Reis, R. A., Carvalho, G. G. P., Siqueira, G. R., \& Bernardes, T. F. (2006). Bagaço de cana-deaçúcar tratado com hidróxido de sódio. Revista Brasileira de Zootecnia, 35(3 suppl), 953-957. https://doi.org/10.1590/s1516-35982006000400003

Prache, S., Priolo, A., \& Grolier, P. (2003). Effect of concentrate finishing on the carotenoid content of perirenal fat in grazing sheep: its significance for discriminating grass-fed, concentrate-fed and concentrate-finished grazing lambs. Animal Science, 77(2), 225-233. https://doi.org/10.1017/s1357729800058963

Priolo, A., Micol, D., Agabriel, J., Prache, S., \& Dransfield, E. (2002). Effect of grass or concentrate feeding systems on lamb carcass and meat quality. Meat Science, 62(2), 179-185. https://doi.org/10.1016/s03091740(01)00244-3

Resconi, V. C., Escudero, A., Beltrán, J. A., Olleta, J. L., Sañudo, C., \& Mar Campo, M. (2011). Color, Lipid Oxidation, Sensory Quality, and Aroma Compounds of Beef Steaks Displayed under Different Levels of Oxygen in a Modified Atmosphere Package. Journal of Food Science, 77(1), S10-S18. https://doi.org/10.1111/j.1750-3841.2011.02506.x 
Riispoa - Regulamento da Inspeção Industrial e Sanitária de Produtos de Origem Animal. (1997). Brasília, DF.

Roça, R. O. (2002). Modificações Post-mortem. PUC-RS. Retrieved April, 2020, from http://pucrs.campus2.br/thompson/Roca105.pdf

Sañudo, C. (2000). Factors affecting carcass and meat quality in lambs. Reunião anual da sociedade brasileira de zootecnia, Recife.

Sañudo, C., Campo, M. M., Sierra, I., María, G. A., Olleta, J. L., \& Santolaria, P. (1997). Breed effect on carcase and meat quality of suckling lambs. Meat Science, 46(4), 357-365. https://doi.org/10.1016/s03091740(97)00030-2

Sañudo, C., Sierra, I., Olleta, J. L., Martin, L., Campo, M. M., Santolaria, P., Wood, J. D., \& Nute, G. R. (1998). Influence of weaning on carcass quality, fatty acid composition and meat quality in intensive lamb production systems. Animal Science, 66(1), 175-187. https://doi.org/10.1017/s1357729800008948

Sarantópoulos, C. I. G. L., \& Pizzinatto, A. (1990). Fatores que afetam a cor das carnes. Coletânea Do Instituto de Tecnologia de Alimentos, 21(1), 1-12. Retrieved from https://pesquisa.bvsalud.org/portal/resource/pt/lil123397

Silva Sobrinho, A. G., Purchas, R. W., Kadim, I. T., \& Yamamoto, S. M. (2005). Características de qualidade da carne de ovinos de diferentes genótipos e idades ao abate. Revista Brasileira de Zootecnia, 34(3), 1070-1078. https://doi.org/10.1590/s1516-35982005000300040

Wheatley, R. (2000). Some recent trends in the analytical chemistry of lipid peroxidation. TrAC Trends in Analytical Chemistry, 19(10), 617-628. https://doi.org/10.1016/s0165-9936(00)00010-8

\section{Copyrights}

Copyright for this article is retained by the author(s), with first publication rights granted to the journal.

This is an open-access article distributed under the terms and conditions of the Creative Commons Attribution license (http://creativecommons.org/licenses/by/4.0/). 